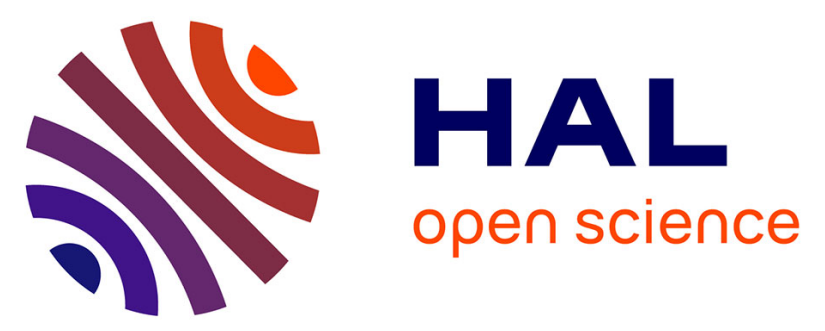

\title{
Iridium and rhodium complexes with the planar chiral thioether ligands in asymmetric hydrogenation of ketones and imines
}

Ekaterina Kozinets, G. Silantyev, N. Belkova, E. Shubina, Rinaldo Poli, E. Manoury

\section{To cite this version:}

Ekaterina Kozinets, G. Silantyev, N. Belkova, E. Shubina, Rinaldo Poli, et al.. Iridium and rhodium complexes with the planar chiral thioether ligands in asymmetric hydrogenation of ketones and imines. Russian Chemical Bulletin, 2013, 62 (3), pp.751-757. 10.1007/s11172-013-0102-5 . hal-02908038

\section{HAL Id: hal-02908038 \\ https://hal.science/hal-02908038}

Submitted on 29 Jul 2021

HAL is a multi-disciplinary open access archive for the deposit and dissemination of scientific research documents, whether they are published or not. The documents may come from teaching and research institutions in France or abroad, or from public or private research centers.
L'archive ouverte pluridisciplinaire HAL, est destinée au dépôt et à la diffusion de documents scientifiques de niveau recherche, publiés ou non, émanant des établissements d'enseignement et de recherche français ou étrangers, des laboratoires publics ou privés. 


\section{Iridium and rhodium complexes with the planar chiral thioether ligands in asymmetric hydrogenation of ketones and imines.}

Ekaterina M. Kozinets, ${ }^{a, b, c}$ Gleb A. Silantyev, ${ }^{c}$ Natalia V. Belkova, ${ }^{* c}$ Elena S. Shubina, ${ }^{c}$ Rinaldo Poli, ${ }^{a, b, d}$ and Eric Manoury*a,b

${ }^{a}$ CNRS, LCC (Laboratoire de Chimie de Coordination), 205 route de Narbonne, BP 44099, F-31077 Toulouse Cedex 4, France CNRS. Fax: +33-561553003; Tel: +33-561333174; Email: eric.manoury@lcc-toulouse.fr.

${ }^{b}$ Université de Toulouse, UPS, INPT, F-31077 Toulouse Cedex 4, France

${ }^{c}$ A. N. Nesmeyanov Institute of Organoelement Compounds, Russian Academy of Sciences, Vavilov Street 28, 119991 Moscow, Russia; Fax: +7-499-1355085; Tel:+7-499-1356448; Email: nataliabelk@ineos.ac.ru.

${ }^{d}$ Institut Universitaire de France, 103, bd Saint-Michel, 75005 Paris, France. 


\begin{abstract}
Rhodium complexes with the planar chiral phosphinoferrocenyl thioether ligands $[\mathrm{Rh}(\mathrm{P}, \mathrm{SR})($ diene $) \mathrm{X}]\left(\mathrm{R}=\mathrm{Me}, \mathrm{Bu}^{\mathrm{t}}, \mathrm{Ph}, \mathrm{Bn}\right.$, diene is cyclooctadiene (COD) or norbornadiene $(\mathrm{NBD}), \mathrm{X}=\mathrm{Cl}, \mathrm{BF} 4)$ catalyze hydrogenation of ketones, imines, and heteroaromatic compounds; in the case of acetophenone, the enantioselectivity reached $60 \%$ ee. Similar iridium complexes demonstrate a good activity in the hydrogenation of imines, the maximal enantioselectivity in the case of $N$-phenyl- $N$-(1-phenylethylidene)amine was about $40 \% e e$.
\end{abstract}

\title{
Introduction
}

Over the last decades, metal_catalyzed asymmetric hydrogenation has become a method of choice for obtaining chiral molecules. ${ }^{1-5}$ Starting from the pioneering work, ${ }^{6}$ ruthenium complexes are generally accepted as the most efficient catalysts. Nonetheless, iridium, rhodium, and more recently, iron complexes, attract growing interest of researches. ${ }^{7}$ Recently, we have shown ${ }^{8}$ that iridium complexes with the planar chiral diphenylphosphinoferrocenyl thioether ligands, viz., [Ir(P,SR)(diene)X], are highly efficient precatalysts of hydrogenation of acetophenone, exhibiting a high activity and enantioselectivity. ${ }^{9}$ Some peculiarities of this catalytic system (a necessity to simultaneously use a base and increased hydrogen pressure) pose a number of questions about the mechanism of this reaction. Rhodium complexes of the type $\left[\mathrm{M}(\text { diene })(\mathrm{L})_{2}\right]^{+}\left(\mathrm{L}_{2}\right.$ is the diphosphine ligand) are well known as catalysts of alkene hydrogenation. ${ }^{10}$ In this connection, the use of the corresponding rhodium complexes, $[\mathrm{Rh}(\mathrm{P}, \mathrm{SR})($ diene $) \mathrm{X}]$, as the models for the studies of the mechanism of ketone hydrogenation seems promising. The preliminary results ${ }^{11}$ showed that the rhodium complexes $[\mathrm{Rh}(\mathrm{P}, \mathrm{SR})($ diene $) \mathrm{X}]$ synthesized by us earlier exhibited catalytic activity in hydrogenation of acetophenone. In the present work, we report the results of the studies on the influence of different factors on the course of this reaction, as well as on the activity of rhodium complexes in the catalytic hydrogenation of a wide range of substrates. 


\section{Results and discussion}

Rhodium complexes with the tert-bulyl substituent at the sulfur atom were used for the studies of the ligand effect (diene, $\mathrm{X}$ ) on the outcome of asymmetric hydrogenation of acetophenone 1 (Scheme 1). Four different complexes were obtained for this ligand: with chloride and tetrafluoroborate anions, as well as with cyclooctadiene (COD) and norbornadiene (NBD) as the leaving diene. ${ }^{11}$ For comparison, the behavior of the iridium complex containing the (P,SBut) and COD ligands and the $\mathrm{Cl}^{-}$anion was studied under similar conditions. The reaction was carried out under the conditions (hydrogen pressure, temperature, reagent ratios) optimized earlier for the iridium complex. ${ }^{9}$ The results of the studies are given in Table 1 and in Fig. 1.

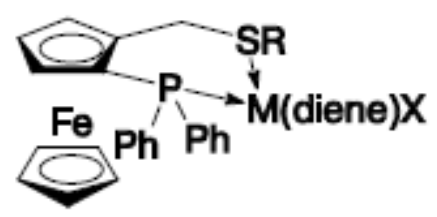

\section{$M(P, S R)(d i e n e) X$}

$\begin{array}{lccc}\mathrm{M} & \mathrm{R} & \text { diene } & \mathrm{X} \\ \mathrm{Ir} & \mathrm{Bu}^{\mathrm{t}} & \mathrm{COD} & \mathrm{Cl} \\ \mathrm{Rh} & \mathrm{Bu}^{\mathrm{t}} & \mathrm{COD} & \mathrm{Cl} \\ \mathrm{Rh} & \mathrm{Bu}^{\mathrm{t}} & \mathrm{COD} & \mathrm{BF}_{4} \\ \mathrm{Rh} & \mathrm{Bu}^{\mathrm{t}} & \mathrm{NBD} & \mathrm{Cl} \\ \mathrm{Rh} & \mathrm{Bu}^{\mathrm{t}} & \mathrm{NBD} & \mathrm{BF}_{4} \\ \mathrm{Rh} & \mathrm{Et} & \mathrm{NBD} & \mathrm{BF}_{4} \\ \mathrm{Rh} & \mathrm{Ph} & \text { NBD } & \mathrm{BF}_{4} \\ \mathrm{Rh} & \mathrm{Bn} & \text { NBD } & \mathrm{BF}_{4}\end{array}$

\section{Scheme 1}

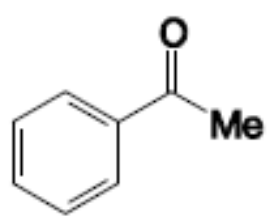

1<smiles>C[C@H](O)c1ccccc1</smiles>

2

Reagents: $[\mathrm{M}(\mathrm{P}, \mathrm{SR})($ diene $) \mathrm{X}], \mathrm{H}_{2}, \mathrm{Pr}^{\mathrm{i}} \mathrm{OH}, \mathrm{MeONa}$. 
Under these conditions, the iridium complex [ $\left.\operatorname{Ir}\left(\mathrm{P}, \mathrm{SBu}^{\mathrm{t}}\right)(\mathrm{COD}) \mathrm{Cl}\right]$ possesses high activity and enantioselectivity and gives the quantitative conversion of acetophenone already after $2 \mathrm{~h}$ (see Table 1, entry 1). The initial activity (conversion of 1 after $1 \mathrm{~h}$ ) of all four rhodium precatalysts was similar, however, it was much lower than the activity of the complex $\left[\operatorname{Ir}\left(\mathrm{P}, \mathrm{SBu}^{t}\right)(\mathrm{COD}) \mathrm{Cl}\right]$ (see Fig. 1). It is interesting that the activity of the complexes with COD is higher than that of the complexes with NBD, which becomes especially noticeable after 5-7 $\mathrm{h}$ of the process. In the case of the COD derivatives, the complexes with $\mathrm{Cl}^{-}$anions are more active than those with $\mathrm{BF}_{4}{ }^{-}$anions (cf. pairs of entries 2 and 4, 7 and 9, 12 and 14), while for the NBD derivatives the situation is reverse ( $c f$. pairs of entries 3 and 5, 8 and 10, 13 and 15). The substrate was completely converted after $72 \mathrm{~h}$ for all the rhodium catalysts.
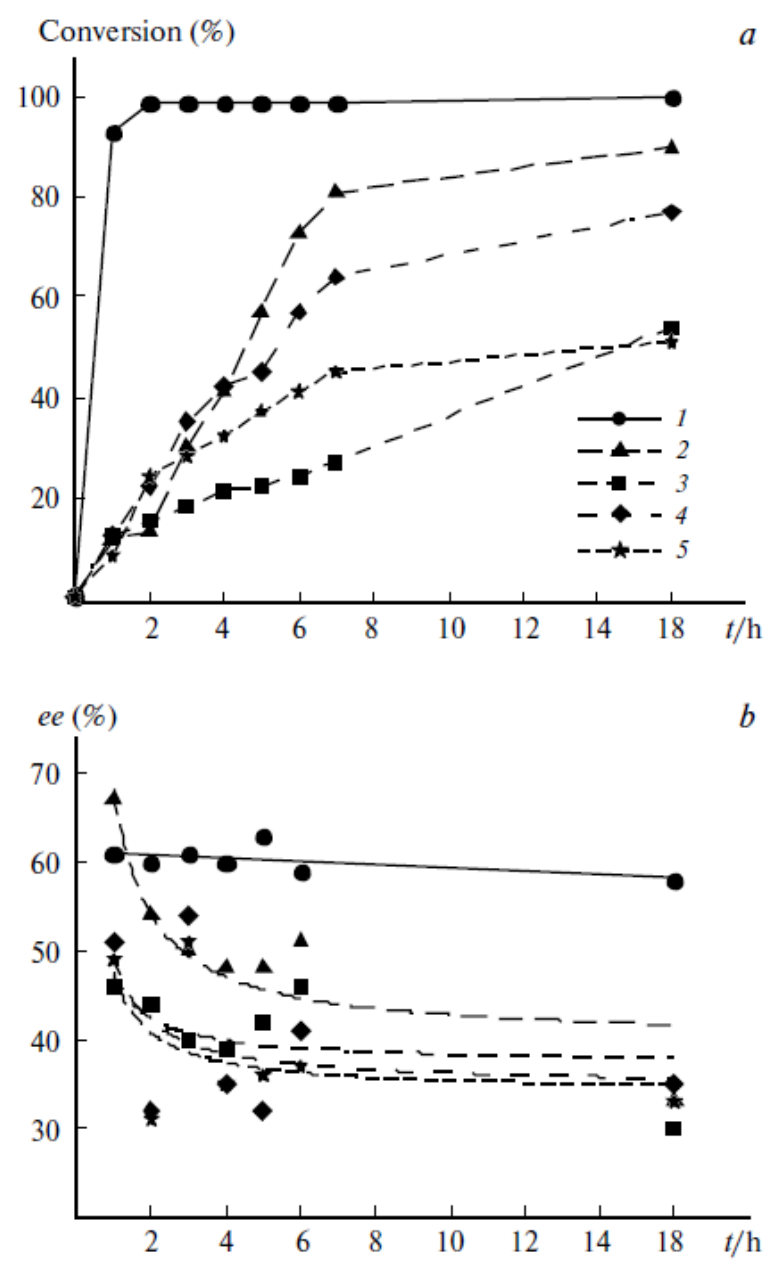

Fig. 1. Conversion of acetophenone $1(a)$ and ee values of $(R)$-1-phenylethanol $2(b)$ versus hydrogenation time for different complexes with the ligand $(R)-\left(\mathrm{P}, \mathrm{SBu}{ }^{t}\right)$ : $\left[\operatorname{Ir}\left(\mathrm{P}, \mathrm{SBu}^{t}\right)(\mathrm{COD}) \mathrm{Cl}\right](1) ;\left[\mathrm{Rh}\left(\mathrm{P}, \mathrm{SBu}{ }^{t}\right)(\mathrm{COD}) \mathrm{Cl}\right](2) ;\left[\mathrm{Rh}\left(\mathrm{P}, \mathrm{SBu}^{\mathrm{t}}\right)(\mathrm{NBD}) \mathrm{Cl}\right](3) ;$ $\left[\mathrm{Rh}\left(\mathrm{P}, \mathrm{SBu}^{\mathrm{t}}\right)(\mathrm{COD})\right] \mathrm{BF}_{4}(4)$, and $\left[\mathrm{Rh}\left(\mathrm{P}, \mathrm{SBu}^{\mathrm{t}}\right)(\mathrm{NBD})\right] \mathrm{BF}_{4}(5)$. 
Table 1. Asymmetric hydrogenation of acetophenone 1 in the presence of the complexes $(R)$ $\left[\mathrm{M}\left(\mathrm{P}, \mathrm{SBu}^{\mathrm{t}}\right)(\right.$ diene $\left.) \mathrm{X}\right]$ depending on the reaction time ${ }^{a}$

\begin{tabular}{|c|c|c|c|c|}
\hline Entry & Catalyst & $t / \mathrm{h}$ & Conv (\%) & $e e(\%)^{b}$ \\
\hline 1 & {$\left[\mathrm{Ir}\left(\mathrm{P}, \mathrm{SBu}^{\mathrm{t}}\right)(\mathrm{COD}) \mathrm{Cl}\right]$} & 2 & 99 & 60 \\
\hline 2 & {$\left[\mathrm{Rh}\left(\mathrm{P}, \mathrm{SBu}^{\mathrm{t}}\right)(\mathrm{COD}) \mathrm{Cl}\right]$} & 2 & 54 & 54 \\
\hline 3 & {$\left[\mathrm{Rh}\left(\mathrm{P}, \mathrm{SBu}^{\mathrm{t}}\right)(\mathrm{NBD}) \mathrm{Cl}\right]$} & 2 & 44 & 44 \\
\hline 4 & {$\left[\mathrm{Rh}\left(\mathrm{P}, \mathrm{SBu}^{\mathrm{t}}\right)(\mathrm{COD})\right] \mathrm{BF}_{4}$} & 2 & 32 & 32 \\
\hline 5 & {$\left[\mathrm{Rh}\left(\mathrm{P}, \mathrm{SBu}^{\mathrm{t}}\right)(\mathrm{NBD})\right] \mathrm{BF}_{4}$} & 2 & 31 & 31 \\
\hline 6 & {$\left[\mathrm{Ir}\left(\mathrm{P}, \mathrm{SBu}^{\mathrm{t}}\right)(\mathrm{COD}) \mathrm{Cl}\right]$} & 5 & $>99$ & 63 \\
\hline 7 & {$\left[\mathrm{Rh}\left(\mathrm{P}, \mathrm{SBu}^{\mathrm{t}}\right)(\mathrm{COD}) \mathrm{Cl}\right]$} & 5 & 57 & 48 \\
\hline 8 & {$\left[\mathrm{Rh}\left(\mathrm{P}, \mathrm{SBu}^{\mathrm{t}}\right)(\mathrm{NBD}) \mathrm{Cl}\right]$} & 5 & 22 & 42 \\
\hline 9 & {$\left[\mathrm{Rh}\left(\mathrm{P}, \mathrm{SBu}^{\mathrm{t}}\right)(\mathrm{COD})\right] \mathrm{BF}_{4}$} & 5 & 45 & 32 \\
\hline 10 & {$\left[\mathrm{Rh}\left(\mathrm{P}, \mathrm{SBu} u^{\mathrm{t}}\right)(\mathrm{NBD})\right] \mathrm{BF}_{4}$} & 5 & 37 & 36 \\
\hline 11 & {$\left[\mathrm{Ir}\left(\mathrm{P}, \mathrm{SBu}^{\mathrm{t}}\right)(\mathrm{COD}) \mathrm{Cl}\right]$} & 16 & $>99$ & 58 \\
\hline 12 & {$\left[\mathrm{Rh}\left(\mathrm{P}, \mathrm{SBu}^{\mathrm{t}}\right)(\mathrm{COD}) \mathrm{Cl}\right]$} & 16 & 90 & 33 \\
\hline 13 & {$\left[\mathrm{Rh}\left(\mathrm{P}, \mathrm{SBu}^{\mathrm{t}}\right)(\mathrm{NBD}) \mathrm{Cl}\right]$} & 16 & 54 & 30 \\
\hline 14 & {$\left[\mathrm{Rh}\left(\mathrm{P}, \mathrm{SBu}^{\mathrm{t}}\right)(\mathrm{COD})\right] \mathrm{BF}_{4}$} & 16 & 77 & 35 \\
\hline 15 & {$\left[\mathrm{Rh}\left(\mathrm{P}, \mathrm{SBu}^{\mathrm{t}}\right)(\mathrm{NBD})\right] \mathrm{BF}_{4}$} & 16 & 51 & 33 \\
\hline
\end{tabular}

${ }^{a}$ Reaction condition: catalyst, $6.4 \cdot 10^{-3} \mathrm{mmol}$; NaOMe, $3.2 \cdot 10^{-2} \mathrm{mmol}$; acetophenone, $3.2 \mathrm{mmol}$, the ratio catalyst:NaOMe: $\mathbf{1}=1: 5: 500,25{ }^{\circ} \mathrm{C}$, and $P\left(\mathrm{H}_{2}\right)=30$ bar. Conversion of acetophenone $\mathbf{1}$ and ee of 1phenylethanol 2 were determined by GC. ${ }^{b}$ The ee values are given with respect to the $R$ configuration.

Earlier, the precatalysts of the type $\left[\mathrm{M}(\text { diene })(\mathrm{L})_{2}\right]^{+}\left(\mathrm{L}_{2}\right.$ is the bisphosphine ligand) were shown to be activated by $\mathrm{H}_{2}$. When alcohols $(\mathrm{ROH})$ were used as the solvent, the complexes of the type $\left[\mathrm{M}(\mathrm{L})_{2}(\mathrm{ROH})_{2}\right]^{+}$were formed, as well as the products of partial or total hydrogenation of the diene (Scheme 2). ${ }^{10 b-d}$

In this case, each pair of precatalysts with different dienes and the same anionic ligands, in principle, should give the same catalytically active complexes $\left[\mathrm{M}(\mathrm{L})_{2}(\mathrm{ROH})_{2}\right]^{+}$. The absence of the induction period and the similar initial (after $1 \mathrm{~h}$ ) activity of all the rhodium complexes indicate a high precatalyst activation rate and the formation of catalytically active species of the same structure. In fact, the ongoing studies of the precatalyst activation under stoichiometric conditions showed the high rate of the diene hydrogenation in alcohol. The reactivity of the complexes $\left[\mathrm{M}(\mathrm{L})_{2}(\mathrm{ROH})_{2}\right]^{+} \mathrm{X}^{-}$should depend only on the 
coordinating ability of the anion $\left(\mathrm{Cl}^{-}\right.$vs. $\left.\mathrm{BF}_{4}^{-}\right)$. We studied the structures of precatalysts $\mathrm{M}$ (diene)(L) $)_{2} \mathrm{X}$ and found that the $\mathrm{Cl}^{-}$ion is in the coordination sphere of the metal, successfully competing with the sulfur atom $(\mathrm{P}, \mathrm{SR})$ of the ligand for binding with the rhodium atom in the solid state. This structure of the complexes is retained in the solutions in low polar non-coordinating solvents like $\mathrm{CDCl}_{3} .{ }^{11} \mathrm{~A}$ similar phenomenon (competitive coordination of the $\mathrm{Cl}-$ ion) can also take place involving the catalytically active forms of the complex, though the solvent used $\left(\operatorname{Pr}^{\mathrm{i}} \mathrm{OH}\right)$ should better stabilize the ionic complexes. To sum up, the different rate of hydrogenation for the $\mathrm{Cl}^{-}$and $\mathrm{BF}_{4}^{-}$derivatives can be due to the difference in the strength of the interaction of the cationic catalytically active species with anion affecting the interaction with the substrate.

\section{Scheme 2}
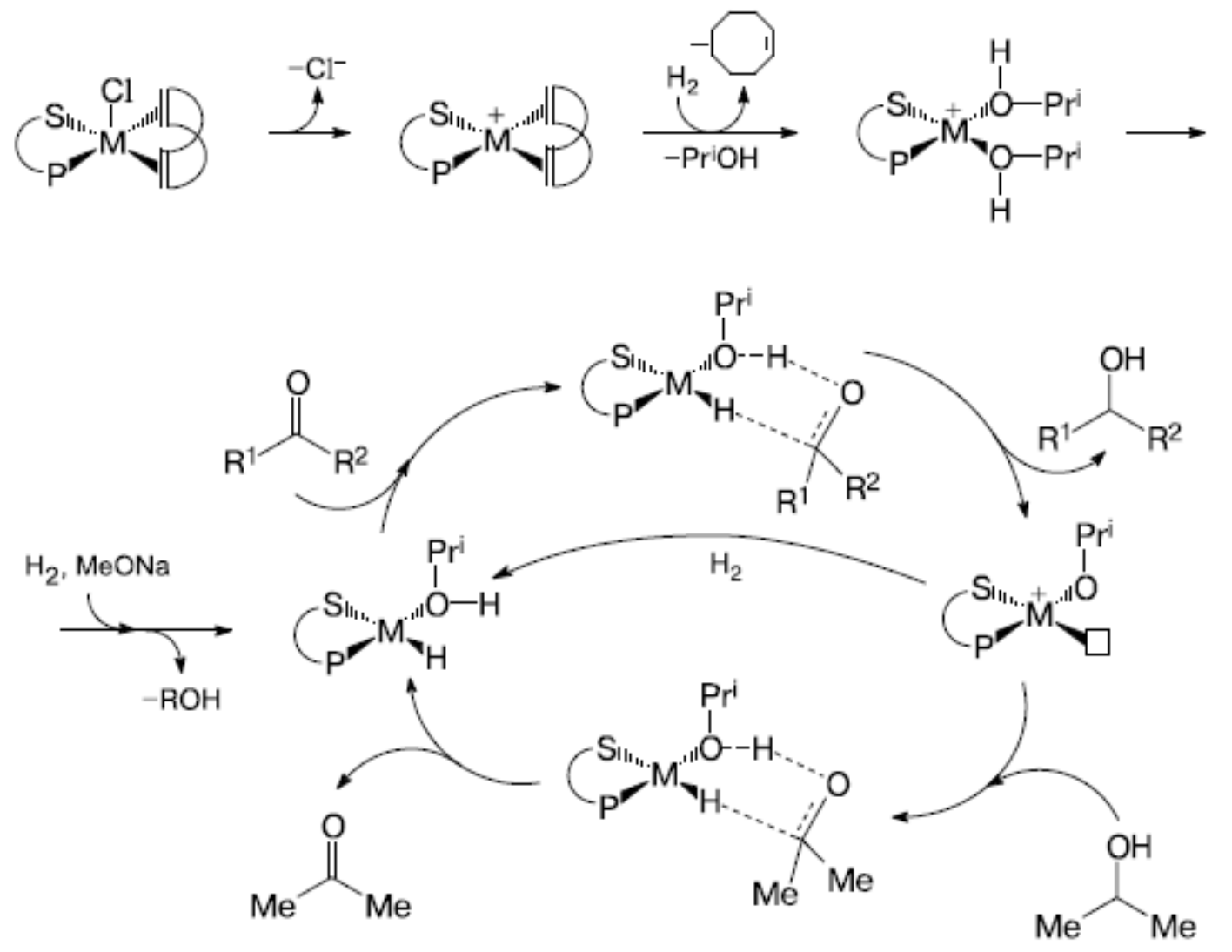

The symbol $\square$ indicates the free coordination site.

While for the iridium complex the enantiomeric excess of the forming 1-phenylethanol 2 remained essentially the same in the course of the reaction, in the case of the chloride rhodium complexes the $e e$ decreased as the conversion increased (see Fig. 1, b). Using $\left[\mathrm{Rh}\left(\mathrm{P}, \mathrm{SBu}^{\mathrm{t}}\right)(\mathrm{COD}) \mathrm{Cl}\right]$ as an example in the control experiment, we showed that 1phenylethanol did not racemize under the catalytic reaction conditions. Therefore, this change 
in enantioselectivity should be caused by the changes in the catalytically active form in the course of the reaction. One of the possible explanations could be the coordination of the reaction product 1-phenylethanol (when it is in excess) to the metal atom instead of PriOH. ${ }^{12}$ However, additional data are required to draw a final conclusion on the mechanisms of the catalyst action and the loss of enantioselectivity.

The influence of substituent $\mathrm{R}$ at the sulfur atom of the phosphinoferrocenyl thioether ligand on the catalytic activity of rhodium complexes was studied on the series of NBD chloride complexes. The complex with $\mathrm{R}=\mathrm{Bu}^{\mathrm{t}}$ appeared to be much more active and possess higher enantioselectivity than the complexes with $\mathrm{Et}, \mathrm{Ph}$, and $\mathrm{Bn}$ substituents (Table 2, Fig. 2). For these three complexes, the extent of conversion did not increase after $5 \mathrm{~h}$ of the reaction, that indicated a low stability of the catalytically active species. The influence of substituent $\mathrm{R}$ at the sulfur atom on the catalytic activity of similar iridium complexes was studied earlier for the complexes with COD ligand. ${ }^{9}$ Iridium complexes possess essentially the same activity (conversion $92-99 \%$ after $2 \mathrm{~h}$ of reaction), however, enantioselectivity to a greater extent depends on the substituent at the sulfur atom and changes from 77 to $43 \%$ in the order $\mathrm{Bn}>\mathrm{Et}>\mathrm{Bu}^{\mathrm{t}}>\mathrm{Ph}^{9}$

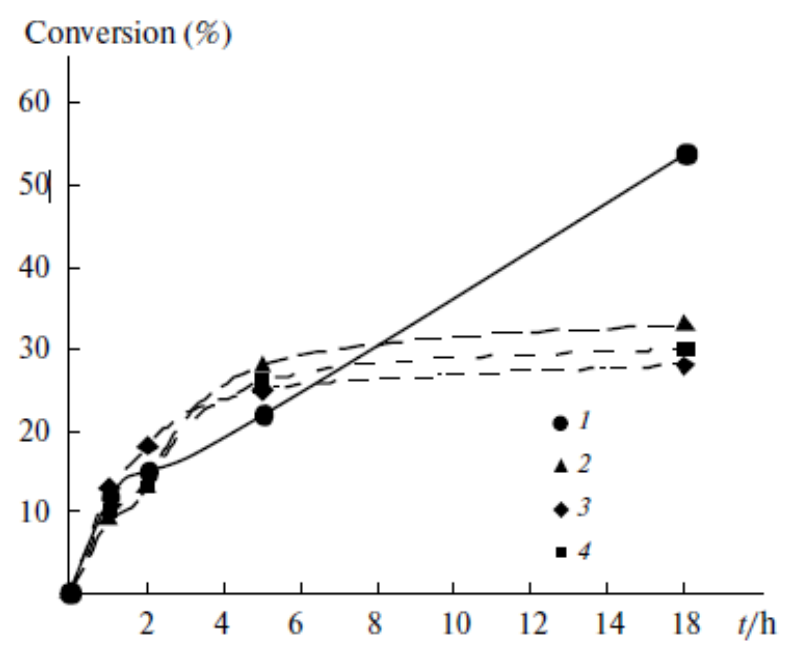

Fig. 2. Conversion of acetophenone 1 versus reaction time for the complexes: $(R)$ $\left[\mathrm{Rh}\left(\mathrm{P}, \mathrm{SBu}^{t}\right)(\mathrm{NBD}) \mathrm{Cl}\right](1),(S)-[\mathrm{Rh}(\mathrm{P}, \mathrm{SEt})(\mathrm{NBD}) \mathrm{Cl}](2),(S)-[\mathrm{Rh}(\mathrm{P}, \mathrm{SPh})(\mathrm{NBD}) \mathrm{Cl}](3)$, and $(S)-[\mathrm{Rh}(\mathrm{P}, \mathrm{SBn})(\mathrm{NBD}) \mathrm{Cl}](4)$. 
Table 2. Hydrogenation of acetophenone 1 depending on the substituent at the $\mathrm{S}$ atom in the complexes $(S)-[\mathrm{Rh}(\mathrm{P}, \mathrm{SR})(\mathrm{NBD}) \mathrm{Cl}]$ and the reaction time ${ }^{a}$

\begin{tabular}{|c|c|c|c|c|}
\hline Entry & Catalyst & $t / h$ & Conv $(\%)$ & $e e(\%)^{\underline{b}}$ \\
\hline 1 & {$[\mathrm{Rh}(\mathrm{P}, \mathrm{SEt})(\mathrm{NBD}) \mathrm{Cl}]$} & 1 & 9 & 27 \\
\hline 2 & {$[\mathrm{Rh}(\mathrm{P}, \mathrm{SPh})(\mathrm{NBD}) \mathrm{Cl}]$} & 1 & 13 & 32 \\
\hline 3 & {$[\mathrm{Rh}(\mathrm{P}, \mathrm{SBn})(\mathrm{NBD}) \mathrm{Cl}]$} & 1 & 12 & 12 \\
\hline 4 & {$[\mathrm{Rh}(\mathrm{P}, \mathrm{SEt})(\mathrm{NBD}) \mathrm{Cl}]$} & 2 & 13 & 25 \\
\hline 5 & {$[\mathrm{Rh}(\mathrm{P}, \mathrm{SPh})(\mathrm{NBD}) \mathrm{Cl}]$} & 2 & 18 & 26 \\
\hline 6 & {$[\mathrm{Rh}(\mathrm{P}, \mathrm{SBn})(\mathrm{NBD}) \mathrm{Cl}]$} & 2 & 13 & 14 \\
\hline 7 & {$[\mathrm{Rh}(\mathrm{P}, \mathrm{SEt})(\mathrm{NBD}) \mathrm{Cl}]$} & 5 & 28 & 22 \\
\hline 8 & {$[\mathrm{Rh}(\mathrm{P}, \mathrm{SPh})(\mathrm{NBD}) \mathrm{Cl}]$} & 5 & 25 & 23 \\
\hline 9 & {$[\mathrm{Rh}(\mathrm{P}, \mathrm{SBn})(\mathrm{NBD}) \mathrm{Cl}]$} & 5 & 26 & 9 \\
\hline 10 & {$[\mathrm{Rh}(\mathrm{P}, \mathrm{SEt})(\mathrm{NBD}) \mathrm{Cl}]$} & 16 & 33 & 21 \\
\hline 11 & {$[\mathrm{Rh}(\mathrm{P}, \mathrm{SPh})(\mathrm{NBD}) \mathrm{Cl}]$} & 16 & 28 & 22 \\
\hline 12 & {$[\mathrm{Rh}(\mathrm{P}, \mathrm{SBn})(\mathrm{NBD}) \mathrm{Cl}]$} & 16 & 30 & 9 \\
\hline
\end{tabular}

${ }^{a}$ Reaction conditions: catalyst $\left(6.4 \cdot 10^{-3} \mathrm{mmol}\right), \mathrm{NaOMe}=1 \%,\left(3.2 \cdot 10^{-2} \mathrm{mmol}\right)$, acetophenone $(3.2 \mathrm{mmol})$, the ratio catalyst:NaOMe: $1=1: 5: 500,25{ }^{\circ} \mathrm{C}$, and $P\left(\mathrm{H}_{2}\right)=30$ Bar. Conversion and $e e$ were determined by GLC. ${ }^{b}$ The $e e$ values are given with respect to the $S$-configuration.

To increase the rate of hydrogenation, we increased the amount of the rhodium precatalyst used (Table 3 ). The use of $1 \%$ of rhodium complexes made it possible to obtain a high extent of conversion already after $2 \mathrm{~h}$ and increase the $e e$ values to $41-51 \%$ in the case of $\mathrm{Bu}^{\mathrm{t}}$ derivatives (see Table 3, entries 1-4, 8-19), but they remained low for the complexes with Et, Ph, and Bn substituents (see Table 3, entries 5-7, 20-22). For NBD complexes, the activity/enantioselectivity values change in the order $\mathrm{Bu}^{\mathrm{t}}>\mathrm{Et}>\mathrm{Ph}>\mathrm{Bn}$. The dependence of the conversion of acetophenone $\mathbf{1}$ on the amount of precatalyst for the four $\left(\mathrm{P}, \mathrm{SBu}^{\mathrm{t}}\right)$ complexes is nonlinear (Fig. 3), that indicates the more complicated mechanism of the reaction than it can be suggested based on the literature data (see Scheme 2). 
Table 3. Hydrogenation of acetophenone 1 depending on the amount of the precatalyst used ${ }^{a}$

\begin{tabular}{|c|c|c|c|c|}
\hline Entry & Catalyst & Amount of catalyst (mol \%) & Conv (\%) & $e e(\%)$ \\
\hline 1 & $(R)-\left[\mathrm{Rh}\left(\mathrm{P}, \mathrm{SBu}^{\mathrm{t}}\right)(\mathrm{COD}) \mathrm{Cl}\right]$ & 0.2 & 16 & $54^{b}$ \\
\hline 2 & $(R)-\left[\mathrm{Rh}\left(\mathrm{P}, \mathrm{SBu}^{\mathrm{t}}\right)(\mathrm{NBD}) \mathrm{Cl}\right]$ & 0.2 & 13 & $44^{b}$ \\
\hline 3 & $(R)-\left[\mathrm{Rh}\left(\mathrm{P}, \mathrm{SBu}^{\mathrm{t}}\right)(\mathrm{COD})\right] \mathrm{BF}_{4}$ & 0.2 & 22 & $32^{b}$ \\
\hline 4 & $(R)-\left[\mathrm{Rh}\left(\mathrm{P}, \mathrm{SBu}^{\mathrm{t}}\right)(\mathrm{NBD})\right] \mathrm{BF}_{4}$ & 0.2 & 24 & $31^{b}$ \\
\hline 5 & $(S)-[\mathrm{Rh}(\mathrm{P}, \mathrm{SEt})(\mathrm{NBD}) \mathrm{Cl}]$ & 0.2 & 13 & $25^{c}$ \\
\hline 6 & $(S)-[\mathrm{Rh}(\mathrm{P}, \mathrm{SPh})(\mathrm{NBD}) \mathrm{Cl}]$ & 0.2 & 18 & $26^{c}$ \\
\hline 7 & $(S)-[\mathrm{Rh}(\mathrm{P}, \mathrm{SBn})(\mathrm{NBD}) \mathrm{Cl}]$ & 0.2 & 13 & $14^{c}$ \\
\hline 8 & $(R)-\left[\mathrm{Rh}\left(\mathrm{P}, \mathrm{SBu}^{\mathrm{t}}\right)(\mathrm{COD}) \mathrm{Cl}\right]$ & 0.3 & 74 & $54^{c}$ \\
\hline 9 & $(R)-\left[\mathrm{Rh}\left(\mathrm{P}, \mathrm{SBu}^{\mathrm{t}}\right)(\mathrm{NBD}) \mathrm{Cl}\right]$ & 0.3 & 27 & $44^{c}$ \\
\hline 10 & $(R)-\left[\mathrm{Rh}\left(\mathrm{P}, \mathrm{SBu}^{\mathrm{t}}\right)(\mathrm{COD})\right] \mathrm{BF}_{4}$ & 0.3 & 51 & $49^{c}$ \\
\hline 11 & $(R)-\left[\mathrm{Rh}\left(\mathrm{P}, \mathrm{SBu}^{\mathrm{t}}\right)(\mathrm{NBD})\right] \mathrm{BF}_{4}$ & 0.3 & 27 & $42^{b}$ \\
\hline 12 & $(R)-\left[\mathrm{Rh}\left(\mathrm{P}, \mathrm{SBu}^{\mathrm{t}}\right)(\mathrm{COD}) \mathrm{Cl}\right]$ & 0.5 & 88 & $49^{b}$ \\
\hline 13 & $(R)-\left[\mathrm{Rh}\left(\mathrm{P}, \mathrm{SBu}^{\mathrm{t}}\right)(\mathrm{NBD}) \mathrm{Cl}\right]$ & 0.5 & 54 & $46^{b}$ \\
\hline 14 & $(R)-\left[\mathrm{Rh}\left(\mathrm{P}, \mathrm{SBu}^{\mathrm{t}}\right)(\mathrm{COD})\right] \mathrm{BF}_{4}$ & 0.5 & 68 & $42^{b}$ \\
\hline 15 & $(R)-\left[\mathrm{Rh}\left(\mathrm{P}, \mathrm{SBu}^{\mathrm{t}}\right)(\mathrm{NBD})\right] \mathrm{BF}_{4}$ & 0.5 & 57 & $51^{b}$ \\
\hline 16 & $(R)-\left[\mathrm{Rh}\left(\mathrm{P}, \mathrm{SBu}^{\mathrm{t}}\right)(\mathrm{COD}) \mathrm{Cl}\right]$ & 1.0 & 99 & $44^{b}$ \\
\hline 17 & $(R)-\left[\mathrm{Rh}\left(\mathrm{P}, \mathrm{SBu}^{\mathrm{t}}\right)(\mathrm{NBD}) \mathrm{Cl}\right]$ & 1.0 & 92 & $51^{b}$ \\
\hline 18 & $(R)-\left[\mathrm{Rh}\left(\mathrm{P}, \mathrm{SBu}^{\mathrm{t}}\right)(\mathrm{COD})\right] \mathrm{BF}_{4}$ & 1.0 & 97 & $41^{b}$ \\
\hline 19 & $(R)-\left[\mathrm{Rh}\left(\mathrm{P}, \mathrm{SBu}^{\mathrm{t}}\right)(\mathrm{NBD})\right] \mathrm{BF}_{4}$ & 1.0 & 93 & $50^{b}$ \\
\hline 20 & $(S)-[\mathrm{Rh}(\mathrm{P}, \mathrm{SEt})(\mathrm{NBD}) \mathrm{Cl}]$ & 1.0 & 51 & $31^{c}$ \\
\hline 21 & $(S)-[\mathrm{Rh}(\mathrm{P}, \mathrm{SPh})(\mathrm{NBD}) \mathrm{Cl}]$ & 1.0 & 39 & $27^{c}$ \\
\hline 22 & $(S)-[\mathrm{Rh}(\mathrm{P}, \mathrm{SBn})(\mathrm{NBD}) \mathrm{Cl}]$ & 1.0 & 40 & $19^{c}$ \\
\hline
\end{tabular}

${ }^{a}$ Reaction conditions: catalyst $\left(6.4 \cdot 10^{-3} \mathrm{mmol}\right)$, NaOMe $\left(3.2 \cdot 10^{-2} \mathrm{mmol}\right), 25^{\circ} \mathrm{C}$, and $P\left(\mathrm{H}_{2}\right)=30$ Bar; the reaction time $2 \mathrm{~h}$. Conversion and ee were determined by GLC. For entries 1-7: acetophenone 1 (3.2 mmol), the ratio catalyst:NaOMe:1 = 1:5:500. For entries 8-11: acetophenone $1(2.1 \mathrm{mmol})$, the ratio catalyst:NaOMe:1 = 1:5:333. For entries 12-19: acetophenone 1 (1.3 mmol), the ratio catalyst:NaOMe:1 = 1:5:200. For entries 16-22: acetophenone $(0.6 \mathrm{mmol})$, the ratio catalyst:NaOMe: $1=1: 5: 100 .{ }^{b}$ The $e e$ values are given with respect to the $R$ configuration. ${ }^{c}$ The $e e$ values are given with respect to the $S$ configuration. 


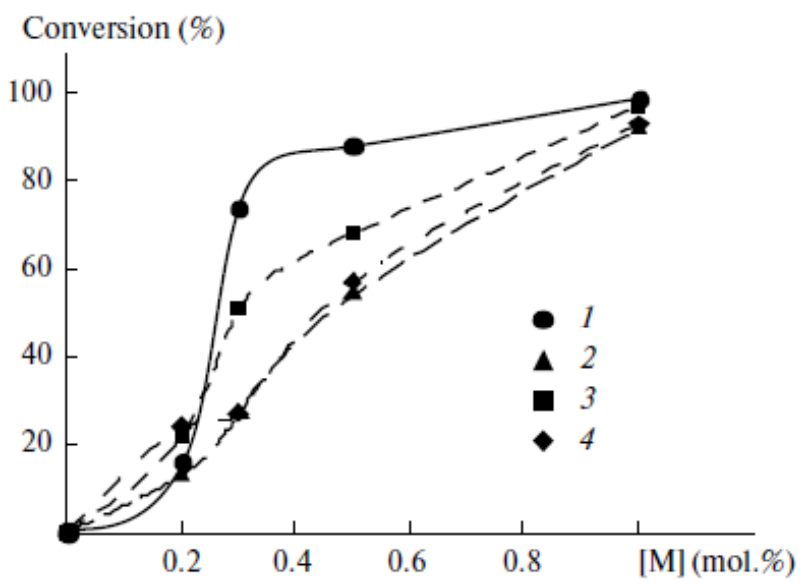

Fig. 3. Conversion of acetophenone 1 versus amount of catalyst ([M]) after $2 \mathrm{~h}$ of the reaction for the complexes $\left[\mathrm{Rh}\left(\mathrm{P}, \mathrm{SBu}^{t}\right)(\mathrm{COD}) \mathrm{Cl}\right](1), \quad\left[\mathrm{Rh}\left(\mathrm{P}, \mathrm{SBu}^{t}\right)(\mathrm{NBD}) \mathrm{Cl}\right](2), \quad\left[\mathrm{Rh}\left(\mathrm{P}, \mathrm{SBu}^{\mathrm{t}}\right)-\right.$ $(\mathrm{COD})] \mathrm{BF}_{4}(3)$, and $\left[\mathrm{Rh}\left(\mathrm{P}, \mathrm{SBu}^{\mathrm{t}}\right)(\mathrm{NBD})\right] \mathrm{BF}_{4}(4)$.

Rhodium complexes were also studied in the hydrogenation of 4-fluoroacetophenone 3. Their activity appeared to be the same and changed in the same order depending on the diene and anion (Scheme 3, Table 4) as in hydrogenation of acetophenone. The monitoring of hydrogenation of 4-fluoroacetophenone $\mathbf{3}$ also showed the decrease in the enantioselectivity with the increase in the conversion, which was observed for all the precatalysts used (see Table 4, entries 2-5, 7-10, 12-15). In the hydrogenation of more sterically hindered tert_bulyl phenyl ketone 4 (see Scheme 3), all the complexes (including iridium one) predictably exhibited the lower catalytic activity and enantioselectivity (see Table 4, entries 16-20). It is interesting that in this reaction, the activity of the rhodium NBD complexes is somewhat higher than that of the COD derivatives, in contrast to the hydrogenation of acetophenone and fluoroacetophenone.

\section{Scheme 3}<smiles>[R]C(=O)c1ccc([R])cc1</smiles>

3, 4<smiles>[R]c1ccc([C@H]([R])O)cc1</smiles>

5,6

3, 5: $R^{1}=F, R^{2}=M e ; 4,6: R^{1}=H, R^{2}=B u^{t}$

Reagents: $[\mathrm{M}(\mathrm{P}, \mathrm{SR})($ diene $) \mathrm{X}], \mathrm{H}_{2}, \mathrm{Pr}^{\mathrm{i}} \mathrm{OH}, \mathrm{MeONa}$. 
Table 4. Asymmetric hydrogenation of 4-fluoroacetophenone (3) and tert-bulyl phenyl ketone (4) depending on the reaction time ${ }^{a}$

\begin{tabular}{|c|c|c|c|c|c|}
\hline Entry & Catalyst & Ketone & $t(\mathrm{~h})$ & Conv (\%) & $e e(\%)^{b}$ \\
\hline 1 & $(R)-\left[\operatorname{Ir}\left(\mathrm{P}, \mathrm{SBu}^{\mathrm{t}}\right)(\mathrm{COD}) \mathrm{Cl}\right]$ & 3 & 2 & 94 & 58 \\
\hline 2 & $(R)-\left[\mathrm{Rh}\left(\mathrm{P}, \mathrm{SBu}^{\mathrm{t}}\right)(\mathrm{COD}) \mathrm{Cl}\right]$ & 3 & 2 & 16 & 60 \\
\hline 3 & $(R)-\left[\mathrm{Rh}\left(\mathrm{P}, \mathrm{SBu}^{\mathrm{t}}\right)(\mathrm{NBD}) \mathrm{Cl}\right]$ & 3 & 2 & 15 & 43 \\
\hline 4 & $(R)-\left[\mathrm{Rh}\left(\mathrm{P}, \mathrm{SBu}^{\mathrm{t}}\right)(\mathrm{COD})\right] \mathrm{BF}_{4}$ & 3 & 2 & 15 & 51 \\
\hline 5 & $(R)-\left[\mathrm{Rh}\left(\mathrm{P}, \mathrm{SBu}^{\mathrm{t}}\right)(\mathrm{NBD})\right] \mathrm{BF}_{4}$ & 3 & 2 & 16 & 52 \\
\hline 6 & $(R)-\left[\operatorname{Ir}\left(\mathrm{P}, \mathrm{SBu}^{\mathrm{t}}\right)(\mathrm{COD}) \mathrm{Cl}\right]$ & 3 & 5 & 99 & 58 \\
\hline 7 & $(R)-\left[\mathrm{Rh}\left(\mathrm{P}, \mathrm{SBu}^{\mathrm{t}}\right)(\mathrm{COD}) \mathrm{Cl}\right]$ & 3 & 5 & 26 & 54 \\
\hline 8 & $(R)-\left[\mathrm{Rh}\left(\mathrm{P}, \mathrm{SBu}^{\mathrm{t}}\right)(\mathrm{NBD}) \mathrm{Cl}\right]$ & 3 & 5 & 25 & 40 \\
\hline 9 & $(R)-\left[\mathrm{Rh}\left(\mathrm{P}, \mathrm{SBu}^{\mathrm{t}}\right)(\mathrm{COD})\right] \mathrm{BF}_{4}$ & 3 & 5 & 26 & 53 \\
\hline 10 & $(R)-\left[\mathrm{Rh}\left(\mathrm{P}, \mathrm{SBu}^{\mathrm{t}}\right)(\mathrm{NBD})\right] \mathrm{BF}_{4}$ & 3 & 5 & 27 & 47 \\
\hline 11 & $(R)-\left[\operatorname{Ir}\left(\mathrm{P}, \mathrm{SBu}^{\mathrm{t}}\right)(\mathrm{COD}) \mathrm{Cl}\right]$ & 3 & 16 & 100 & 57 \\
\hline 12 & $(R)-\left[\mathrm{Rh}\left(\mathrm{P}, \mathrm{SBu}^{\mathrm{t}}\right)(\mathrm{COD}) \mathrm{Cl}\right]$ & 3 & 16 & 86 & 29 \\
\hline 13 & $(R)-\left[\mathrm{Rh}\left(\mathrm{P}, \mathrm{SBu}^{\mathrm{t}}\right)(\mathrm{NBD}) \mathrm{Cl}\right]$ & 3 & 16 & 41 & 36 \\
\hline 14 & $(R)-\left[\mathrm{Rh}\left(\mathrm{P}, \mathrm{SBu}^{\mathrm{t}}\right)(\mathrm{COD})\right] \mathrm{BF}_{4}$ & 3 & 16 & 67 & 42 \\
\hline 15 & $(R)-\left[\mathrm{Rh}\left(\mathrm{P}, \mathrm{SBu}^{\mathrm{t}}\right)(\mathrm{NBD})\right] \mathrm{BF}_{4}$ & 3 & 16 & 64 & 33 \\
\hline 16 & $(R)-\left[\operatorname{Ir}\left(\mathrm{P}, \mathrm{SBu}^{\mathrm{t}}\right)(\mathrm{COD}) \mathrm{Cl}\right]$ & 4 & 16 & 49 & 14 \\
\hline 17 & $(R)-\left[\mathrm{Rh}\left(\mathrm{P}, \mathrm{SBu}^{\mathrm{t}}\right)(\mathrm{COD}) \mathrm{Cl}\right]$ & 4 & 16 & 15 & -9 \\
\hline 18 & $(R)-\left[\mathrm{Rh}\left(\mathrm{P}, \mathrm{SBu}^{\mathrm{t}}\right)(\mathrm{NBD}) \mathrm{Cl}\right]$ & 4 & 16 & 20 & 10 \\
\hline 19 & $(R)-\left[\mathrm{Rh}\left(\mathrm{P}, \mathrm{SBu}^{\mathrm{t}}\right)(\mathrm{COD})\right] \mathrm{BF}_{4}$ & 4 & 16 & 13 & 0 \\
\hline 20 & $(R)-\left[\mathrm{Rh}\left(\mathrm{P}, \mathrm{SBu}^{\mathrm{t}}\right)(\mathrm{NBD})\right] \mathrm{BF}_{4}$ & 4 & 16 & 25 & 11 \\
\hline
\end{tabular}

${ }^{a}$ Reaction conditions: catalyst $\left(6.4 \cdot 10^{-3} \mathrm{mmol}\right), \mathrm{NaOMe}\left(3.2 \cdot 10^{-2} \mathrm{mmol}\right)$, the substrate $(3.2 \mathrm{mmol})$, the ratio catalyst:NaOMe:the substrate $=1: 5: 500,25^{\circ} \mathrm{C}$, and $P\left(\mathrm{H}_{2}\right)=30$ Bar. Conversion of ketones 3 and $\mathbf{4}$ and $e e$ of alcohols $\mathbf{5}$ and $\mathbf{6}$ were determined by GLC. $b$ The $e e$ values are given with respect to the $R$-configuration.

Dialkyl ketones are more challenging substrates for the asymmetric hydrogenation. We studied activity of complexes with the $\left(\mathrm{P}, \mathrm{SBu}^{\mathrm{t}}\right)$ ligands in the hydrogenation of cyclohexyl methyl ketone 7 (Scheme 4, Table 5). It is interesting that even when 0.2 mol.\% of the catalyst was used, the activity of the rhodium complexes appeared to be higher than that of the iridium complex, and 1-cyclohexylethanol (8) was obtained in quantitative yield 
already after $16 \mathrm{~h}$ for the Rh catalysts, with the order of their activity being the same as in the hydrogenation of acetophenones (Fig. 4). Unfortunately, the enantioselectivity of the reaction under these (unoptimized) conditions was very low (ee $<10 \%$ ).

\section{Scheme 4}<smiles>CC(=O)C1CCCCC1</smiles>

7

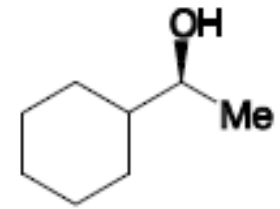

8

Reagents: $[\mathrm{M}(\mathrm{P}, \mathrm{SR})($ diene $) \mathrm{X}], \mathrm{H}_{2}, \mathrm{Pr}^{\mathrm{i}} \mathrm{OH}, \mathrm{MeONa}$.

Table 5. Asymmetric hydrogenation of cyclohexyl methyl ketone (7) depending on the reaction time ${ }^{a}$

\begin{tabular}{|c|c|c|c|c|}
\hline Entry & Catalyst & $t(\mathrm{~h})$ & Conv (\%) & $e e(\%)^{b}$ \\
\hline 1 & $(R)-\left[\operatorname{Ir}\left(\mathrm{P}, \mathrm{SBu}^{\mathrm{t}}\right)(\mathrm{COD}) \mathrm{Cl}\right]$ & 2 & 52 & -7 \\
\hline 2 & $(R)-\left[\mathrm{Rh}\left(\mathrm{P}, \mathrm{SBu}^{\mathrm{t}}\right)(\mathrm{COD}) \mathrm{Cl}\right]$ & 2 & 49 & 3 \\
\hline 3 & $(R)-\left[\mathrm{Rh}\left(\mathrm{P}, \mathrm{SBu}^{\mathrm{t}}\right)(\mathrm{NBD}) \mathrm{Cl}\right]$ & 2 & 25 & 6 \\
\hline 4 & $(R)-\left[\mathrm{Rh}\left(\mathrm{P}, \mathrm{SBu}^{\mathrm{t}}\right)(\mathrm{COD})\right] \mathrm{BF}_{4}$ & 2 & 45 & 3 \\
\hline 5 & $(R)-\left[\mathrm{Rh}\left(\mathrm{P}, \mathrm{SBu}^{\mathrm{t}}\right)(\mathrm{NBD})\right] \mathrm{BF}_{4}$ & 2 & 45 & 9 \\
\hline 6 & $(R)-\left[\operatorname{Ir}\left(\mathrm{P}, \mathrm{SBu}^{\mathrm{t}}\right)(\mathrm{COD}) \mathrm{Cl}\right]$ & 5 & 66 & -10 \\
\hline 7 & $(R)-\left[\mathrm{Rh}\left(\mathrm{P}, \mathrm{SBu}^{\mathrm{t}}\right)(\mathrm{COD}) \mathrm{Cl}\right]$ & 5 & 89 & 4 \\
\hline 8 & $(R)-\left[\mathrm{Rh}\left(\mathrm{P}, \mathrm{SBu}^{\mathrm{t}}\right)(\mathrm{NBD}) \mathrm{Cl}\right]$ & 5 & 30 & 7 \\
\hline 9 & $(R)-\left[\mathrm{Rh}\left(\mathrm{P}, \mathrm{SBu}^{\mathrm{t}}\right)(\mathrm{COD})\right] \mathrm{BF}_{4}$ & 5 & 86 & 4 \\
\hline 10 & $(R)-\left[\mathrm{Rh}\left(\mathrm{P}, \mathrm{SBu}^{\mathrm{t}}\right)(\mathrm{NBD})\right] \mathrm{BF}_{4}$ & 5 & 79 & 7 \\
\hline 11 & $(R)-\left[\operatorname{Ir}\left(\mathrm{P}, \mathrm{SBu}^{\mathrm{t}}\right)(\mathrm{COD}) \mathrm{Cl}\right]$ & 16 & 80 & -9 \\
\hline 12 & $(R)-\left[\mathrm{Rh}\left(\mathrm{P}, \mathrm{SBu}^{\mathrm{t}}\right)(\mathrm{COD}) \mathrm{Cl}\right]$ & 16 & 100 & 4 \\
\hline 13 & $(R)-\left[\mathrm{Rh}\left(\mathrm{P}, \mathrm{SBu}^{\mathrm{t}}\right)(\mathrm{NBD}) \mathrm{Cl}\right]$ & 16 & 99 & 6 \\
\hline 14 & $(R)-\left[\mathrm{Rh}\left(\mathrm{P}, \mathrm{SBu}^{\mathrm{t}}\right)(\mathrm{COD})\right] \mathrm{BF}_{4}$ & 16 & 100 & 4 \\
\hline 15 & $(R)-\left[\mathrm{Rh}\left(\mathrm{P}, \mathrm{SBu}^{\mathrm{t}}\right)(\mathrm{NBD})\right] \mathrm{BF}_{4}$ & 16 & 100 & 6 \\
\hline
\end{tabular}

a Reaction conditions: catalyst $\left(6.4 \cdot 10^{-3} \mathrm{mmol}\right), \mathrm{NaOMe}\left(3.2 \cdot 10^{-2} \mathrm{mmol}\right)$, cyclohexyl methyl ketone 7 (3.2 mmol), the ratio catalyst: $\mathrm{NaOMe} / 7=1: 5: 500,25{ }^{\circ} \mathrm{C}$, and $P\left(\mathrm{H}_{2}\right)=30$ Bar. Conversion of 7 and ee of $1-$ cyclohexylethanol (8) were determined by GLC. $b$ The $e e$ values are given with respect to the $R$-configuration. 


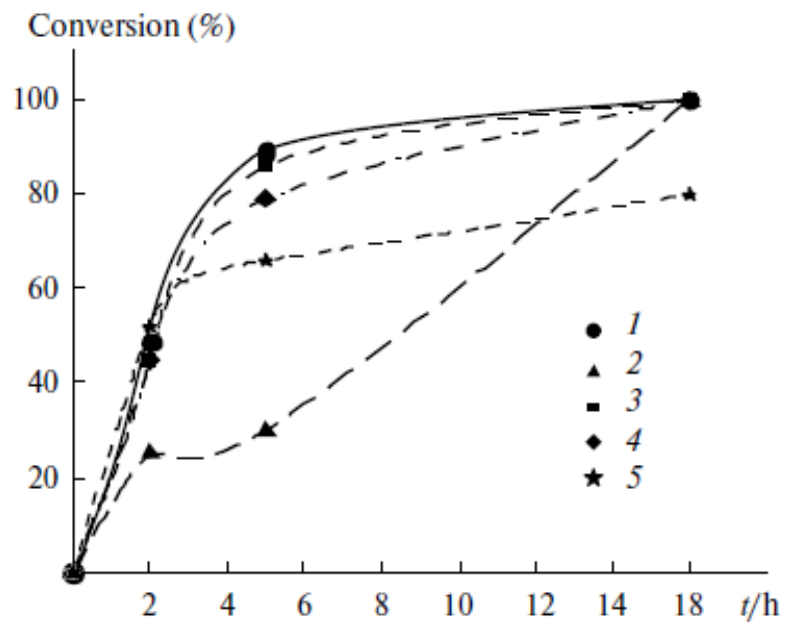

Fig. 4. Conversion of cyclohexyl methyl ketone 7 versus hydrogenation time with the complexes: $\left[\mathrm{Rh}\left(\mathrm{P}, \mathrm{SBu}^{t}\right)(\mathrm{COD}) \mathrm{Cl}\right](1),\left[\mathrm{Rh}\left(\mathrm{P}, \mathrm{SBu}{ }^{\dagger}\right)(\mathrm{NBD}) \mathrm{Cl}\right](2),\left[\mathrm{Rh}\left(\mathrm{P}, \mathrm{SBu}^{t}\right)(\mathrm{COD})\right] \mathrm{BF}_{4}(3)$, $\left[\mathrm{Rh}\left(\mathrm{P}, \mathrm{SBu}^{\mathrm{t}}\right)(\mathrm{NBD})\right] \mathrm{BF}_{4}(4)$, and $\left[\mathrm{Ir}\left(\mathrm{P}, \mathrm{SBu}^{\mathrm{t}}\right)(\mathrm{COD}) \mathrm{Cl}\right](5)$.

Besides, the activity of iridium and rhodium complexes with the $\left(\mathrm{P}, \mathrm{SBu}^{\mathrm{t}}\right)$ ligand was tested in the asymmetric hydrogenation of imines ${ }^{4}$ (taken $N$-phenyl- $N$-(1-phenylethylidene)amine (9) as an example) (Scheme 5, Table 6) and quinaldine ${ }^{5} \mathbf{1 0}$ (Scheme 6, Table 7). Good conversion was obtained in both reactions only for the iridium complex. A moderate ee value was obtained only for the reduction of imine 9 in the presence of the iridium complex, the enantioselectivity of the rhodium complexes in this reaction and all the complexes in the hydrogenation of quinaldine $\mathbf{1 0}$ was low.

\section{Scheme 5}<smiles>C/C(=N\c1ccccc1)c1ccccc1</smiles>

9<smiles>C[C@H](Nc1ccccc1)c1ccccc1</smiles>

11

Reagents and conditions: $[\mathrm{M}(\mathrm{P}, \mathrm{SR})($ diene $) \mathrm{X}](1 \%), \mathrm{I}_{2}(3 \%), \mathrm{H}_{2}, \mathrm{CH}_{2} \mathrm{Cl}_{2}, 16 \mathrm{~h}$.

Table 6. Asymmetric hydrogenation of $N$-phenyl- $N$-(1-phenylethylidene)amine (9) ${ }^{a}$

\begin{tabular}{|c|c|c|c|}
\hline Entry & Catalyst & Conv $(\%)$ & $e e(\%)^{b}$ \\
\hline 1 & $(R)-\left[\operatorname{Ir}\left(\mathrm{P}^{b} \mathrm{SBu}^{\mathrm{t}}\right)(\mathrm{COD}) \mathrm{Cl}\right]$ & 100 & $40(R)$ \\
\hline 2 & $(R)-\left[\mathrm{Rh}\left(\mathrm{P}, \mathrm{SBu}{ }^{\mathrm{t}}\right)(\mathrm{COD}) \mathrm{Cl}\right]$ & 27 & $5(S)$ \\
\hline
\end{tabular}




\begin{tabular}{|c|c|c|c|}
\hline 3 & $(R)-\left[\mathrm{Rh}\left(\mathrm{P}, \mathrm{SBu}^{\mathrm{t}}\right)(\mathrm{NBD}) \mathrm{Cl}\right]$ & 42 & $7(S)$ \\
\hline 4 & $(R)-\left[\mathrm{Rh}\left(\mathrm{P}_{,} \mathrm{SBu}^{\mathrm{t}}\right)(\mathrm{COD})\right] \mathrm{BF}_{4}$ & 24 & $5(S)$ \\
\hline 5 & $(R)-\left[\mathrm{Rh}\left(\mathrm{P}, \mathrm{SBu}^{\mathrm{t}}\right)(\mathrm{NBD})\right] \mathrm{BF}_{4}$ & 44 & $10(S)$ \\
\hline
\end{tabular}

${ }^{a}$ Reaction conditions: catalyst $\left(6.4 \cdot 10^{-3} \mathrm{mmol}\right), \mathrm{I}_{2}(1.9 \cdot 10-2 \mathrm{mmol}), N$-phenyl- $N$-(1-phenylethylidene)amine (9) $(0.6 \mathrm{mmol})$, the ratio catalyst: $\mathrm{I}_{2}: 9=1: 3: 100,25^{\circ} \mathrm{C}$, and $P\left(\mathrm{H}_{2}\right)=30$ Bar. Conversion and ee of amine 11 were determined by GLC. ${ }^{b}$ The configuration of formed amine $\mathbf{1 1}$ is given in parentheses.

\section{Scheme 6}

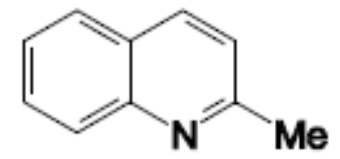

10

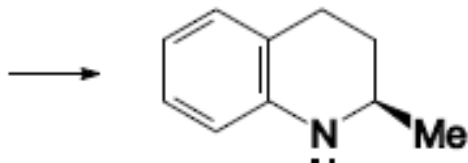

H

12

Reagents and conditions: $[\mathrm{M}(\mathrm{P}, \mathrm{SR})($ diene $) \mathrm{X}](1 \%), \mathrm{I}_{2}(3 \%), \mathrm{H}_{2}, \mathrm{CH}_{2} \mathrm{Cl}_{2}, 16 \mathrm{~h}$.

Table 7. Asymmetric hydrogenation of quinaldine $\mathbf{1 0}^{a}$

\begin{tabular}{|c|c|c|c|}
\hline Entry & Catalyst & Conv (\%) & $e e(\%)^{b}$ \\
\hline 1 & $(R)-\left[\operatorname{Ir}\left(\mathrm{P}, \mathrm{SBu}{ }^{\mathrm{t}}\right)(\mathrm{COD}) \mathrm{Cl}\right]$ & 100 & $5(S)$ \\
\hline 2 & $(R)-\left[\mathrm{Rh}\left(\mathrm{P}, \mathrm{SBu}^{\mathrm{t}}\right)(\mathrm{COD}) \mathrm{Cl}\right]$ & 5 & $8(R)$ \\
\hline 3 & $(R)-\left[\mathrm{Rh}\left(\mathrm{P}, \mathrm{SBu}^{\mathrm{t}}\right)(\mathrm{NBD}) \mathrm{Cl}\right]$ & 28 & $11(R)$ \\
\hline 4 & $(R)-\left[\mathrm{Rh}\left(\mathrm{P}, \mathrm{SBu}^{\mathrm{t}}\right)(\mathrm{COD})\right] \mathrm{BF}_{4}$ & 7 & $20(R)$ \\
\hline 5 & $(R)-\left[\mathrm{Rh}\left(\mathrm{P}, \mathrm{SBu}^{\mathrm{t}}\right)(\mathrm{NBD})\right] \mathrm{BF}_{4}$ & 12 & $27(R)$ \\
\hline
\end{tabular}

${ }^{a}$ Reaction conditions: catalyst $\left(6.4 \cdot 10^{-3} \mathrm{mmol}\right), \mathrm{I}_{2}(1.9 \cdot 10-2 \mathrm{mmol})$, quinaldine $10(0.6 \mathrm{mmol})$, the ratio catalyst: $\mathrm{I}_{2}: \mathbf{1 0}=1: 3: 100,25{ }^{\circ} \mathrm{C}$, and $P\left(\mathrm{H}_{2}\right)=30$ Bar. Conversion and $e e$ of the product $\mathbf{1 2}$ were determined by GLC. ${ }^{b}$ The configuration of formed tetrahydroquinaldine $\mathbf{1 2}$ is given in parentheses.

In conclusion, the rhodium complexes $[\mathrm{Rh}(\mathrm{P}, \mathrm{SR})(\mathrm{diene}) \mathrm{X}]$ studied were predictably less efficient in the catalytic asymmetric hydrogenation of acetophenone under the conditions providing the high activity and enantioselectivity for the iridium complex $\left[\operatorname{Ir}\left(\mathrm{P}, \mathrm{SBu}^{\mathrm{t}}\right)(\mathrm{COD}) \mathrm{Cl}\right]$. For the series of $\mathrm{Rh}\left(\mathrm{P}, \mathrm{SBu}^{\mathrm{t}}\right)$ derivatives, the rate of hydrogenation and the enantioselectivity change in the order $\mathrm{COD}-\mathrm{Cl}>\mathrm{COD}-\mathrm{BF}_{4}>\mathrm{NBD}-\mathrm{BF}_{4}>\mathrm{NBD}-\mathrm{Cl}$. For the NBD complexes, the activity/enantioselectivity values change in the order But $>\mathrm{Et}>\mathrm{Ph}$ $>\mathrm{Bn}$. The collected data on the influence of different factors on the rate and the enantioselectivity of hydrogenation of alkyl aryl ketones (for example, nonlinear dependence of acetophenone conversion on the amount of precatalyst, changes in enantioselectivity in the 
course of the reaction, while maintaining the catalytic activity) suggest a more complicated mechanism of the reaction than can be suggested based on the literature data. The studies performed on the catalytic hydrogenation of various challenging substrates showed that the use of rhodium complexes for the reduction of dialkyl ketones is a promising approach, while the iridium complex exhibited a good activity in the catalytic hydrogenation of imines.

\section{Experimental}

All the reactions were carried out under argon using the Schlenk technique. Solvents were purified by distillation under argon before use. Rhodium ${ }^{11}$ and iridium ${ }^{8}$ complexes were $^{2}$ obtained according to the known procedure from $[\operatorname{RhCl}(\mathrm{COD})]_{2}, \quad[\operatorname{RhCl}(\mathrm{NBD})]_{2}$, $\left[\mathrm{Rh}(\mathrm{COD})_{2}\right] \mathrm{BF}_{4}$, or $[\mathrm{IrCl}(\mathrm{COD})]_{2}$ and $(R / S)$-2-diphenylphosphinoferrocenyl thioether ligands $\left(\mathrm{R}=\mathrm{Et}, \mathrm{Bu}{ }^{\mathrm{t}}, \mathrm{Ph}, \mathrm{Bn}\right) .{ }^{13}$ Ketones were used in the reactions without preliminary purification. Quinaldine 10 was purified by distillation in vacuo. The presence of impurities in all the substrates was monitored by GLC before use. $N$-Phenyl- $N$-(1-phenylethylidene)amine (9) was synthesized from aniline and acetophenone (1) according to the standard procedure using a Dean-Stark trap. ${ }^{14}$ Conversion of starting compounds and optical purity of products were determined by GLC on Supelco BETADEX ${ }^{\mathrm{TM}} 225$ (for ketones) and Varian Chirasil_DEX C (for imines) instruments equipped with chiral columns.

Asymmetric hydrogenation of ketones (general procedure). A solution containing a precatalyst $\left(6.4 \cdot 10^{-3} \mathrm{mmol}\right), \mathrm{MeONa}\left(3.2 \cdot 10^{-2} \mathrm{mmol}, 5\right.$ equiv. $)$, and the substrate $(3.2 \mathrm{mmol}$, 500 equiv.) in isopropyl alcohol $(2 \mathrm{~mL})$ was poured in a $5-\mathrm{mL}$ glass vial, which was placed under argon in a steel autoclave equipped with magnetic stirrer. The autoclave was filled with hydrogen under the pressure of $30 \mathrm{Bar}$, and the mixture was stirred at room temperature for a required time (see Tables 1-5). The reaction products were isolated by preparative column chromatography using dichloromethane as an eluent. Enantiomerically enriched 1phenylethanol was obtained by this procedure with [ $\operatorname{Ir}(\mathrm{P}, \mathrm{SBut})(\mathrm{COD}) \mathrm{Cl}]$ as a precatalyst in $96 \%$ yield (ee $61 \%$ ).

Enantiomeric stability of 1_phenylethanol. A solution containing $\left[\mathrm{Rh}\left(\mathrm{P}, \mathrm{SBu}^{\mathrm{t}}\right)\right.$ $(\mathrm{COD}) \mathrm{Cl}]\left(6.4 \cdot 10^{-3} \mathrm{mmol}\right), \mathrm{MeONa}\left(3.2 \cdot 10^{-2} \mathrm{mmol}, 5\right.$ equiv. $)$ and enantiomerically enriched 1-phenylethanol (3.2 mmol, 500 equiv., ee 61\%) in isopropyl alcohol (2 mL) was poured in a 5-mL glass vial, which was placed under argon in a steel autoclave equipped with a magnetic 
stirrer. The autoclave was filled with hydrogen under the pressure of $30 \mathrm{Bar}$, and the mixture was stirred at room temperature for $16 \mathrm{~h}$. The reaction products were isolated by preparative column chromatography using dichloromethane as an eluent. The yield was $100 \%$, ee $59 \%$.

Asymmetric hydrogenation of imines (general procedure). A solution containing a precatalyst $\left(6.4 \cdot 10^{-3} \mathrm{mmol}\right), \mathrm{I}_{2}\left(1.9 \cdot 10^{-2} \mathrm{mmol}, 3\right.$ equiv.), and a substrate $(0.64 \mathrm{mmol}, 100$ equiv.) in dichloromethane $(2 \mathrm{~mL})$ was poured into a $5-\mathrm{mL}$ glass vial, which was placed under argon in a steel autoclave equipped with a magnetic stirrer. The autoclave was filled with hydrogen under the pressure of $30 \mathrm{Bar}$, and the mixture was stirred at room temperature for the required time (see Tables 6 and 7). The reaction products were isolated by preparative column chromatography using dichloromethane as an eluent.

\section{Acknowledgment}

The work was carried out within the Joint European Laboratory "Homogeneous Catalysis for the Sustainable Development" and was financially supported by the Russian Foundation for Basic Research (Project No. 12-03-31326) and the France National Center of Scientific Studies (Joint Grant with RFBR No. 12_03_93112). The authors are also grateful to the French Embassy in Moscow for the fellowship grant.

\section{References}

1. W. Tang, X. Zhang, Chem. Rev., 2003, 103, 3029.

2. R. Malacea, E. Manoury, R. Poli, Coord. Chem. Rev., 2010, 254, 729.

3. (a) X. Cui, K. Burgess, Chem. Rev., 2005, 105, 3272; (b) S. J. Roseblade, A. Pfalz, Acc. Chem. Res., 2007, 40, 1402; (c) T. L. Church, P. G. Andersson, Coord. Chem. Rev., 2008, 252, 513.

4. (a) N. Fleury_Brégeot, V. de la Fuente, S. Castillon, C. Claver, ChemCatChem, 2010, 2, 1346; (b) A. Fabrello, A. Bachelier, M. Urrutigoity, P. Kalck, Coord. Chem. Rev., 2010, 254, 273; (c) J.-H. Xie, S.-F. Zhu, Q.-L. Zhou, Chem. Rev., 2011, 111, 1713.

5. (a) Q._L. Zhou, Acc. Chem. Res., 2007, 40, 1357; (b) D.-S. Weng, Q.-A. Chen, Q._L. Zhou, Chem. Rev., 2012, 112, 2557.

6. T. Okhuma, H. Ooka, S. Hashigushi, T. Ikariya, R. Noyori, J. Am. Chem. Soc., 1995, 117, 2675.

7. (a) A. A. Mikhailine, M. I. Maishan, A. J. Lough, R. H. Morris, J. Am. Chem. Soc., 2012, 134, 12266; (b) S. Enthaler, K. Junge, M. Beller, Angew. Chem., Int. Ed., 2008, 47, 3317; (c) M. Darwish, M. Wills, Catal. Sci. Technol., 2012, 2, 243.

8. R. Malacea, E. Manoury, L. Routaboul, J.-C. Daran, R. Poli, J. P. Dunne, A. C. Withwood, C. Godard, S. B. Duckett, Eur. J. Inorg. Chem., 2006, 9, 1803.

9. E. Le Roux, R. Malacea, E. Manoury, R. Poli, L. Gonsalvi, M. Peruzzini, Adv. Synth. Catal., 2007, 349, 309.

10. (a) H. J. Drexler, W. Baumann, A. Spannenberg, C. Fischer, D. Heller, J. Organomet. Chem., 2001, 621, 89; (b) A. Preetz, H. J. Drexler, C. Fischer, Z. Dai, A. Borner, W. Baumann, A. Spannenberg, R. Thede, D. Heller, Chem. Eur. J., 2008, 14, 1445; (c) A. Preetz, C. Fischer, C. Kohrt, H. J. Drexler, W. Baumann, D. 
Heller, Organometallics, 2011, 30, 5155; (d) I. D. Gridnev, E. Alberico, S. Gladiali, Chem. Commun., 2012, 48, 2186.

11. E. M. Kozinets, O. Koniev, O. A. Fillipov, J.-C. Daran, R. Poli, E. S. Shubina, N. V. Belkova, E. Manoury, Dalton Trans., 2012, 41, 11849.

12. J. Ito, T. Teshima, H. Nishiyama, Chem. Commun., 2012, 48, 1105.

13. L. Routaboul, S. Vincendeau, J._C. Daran, E. Manoury, Tetrahedron: Asymmetry, 2005, 16, 2685.

14. J. March, Advanced Organic Chemistry, 3rd ed., Wiley-Interscience, New Yok, 1985, p. 796. 